\title{
Jane Grey, 'Manful' Combat, and the Female Reader in Early Modern England
}

\author{
EDITH SNOOK \\ University of New Brunswick
}

Cet essai considère Jane Grey et les idéaux de la lecture féminine au début des temps modernes. À travers trois avenues de recherche, cet essai met en lumière l'influence de l'idéologie politique sur les pratiques de lecture de Jane Grey et sur l'émergence historique de la lecture féminine. L'essai examine d'abord la fonction de la lecture de la Bible dans des recueils, circulant en imprimés ou en manuscrits, et que Jane a créée peu avant sa mort. L'essai étudie ensuite la publication des textes de Jane Grey par des penseurs importants de la Réforme, tels que John Foxe et Miles Coverdale, qui sont également intéressés à son statut en tant que lectrice et acceptent à la fois son modèle de lectrice et sa féminité militante. Enfin, l'essai considère la représentation de Jane Grey en tant que lectrice dans des récits littéraires du début des temps modernes, dans lesquels Jane n'apparaît pas comme une militante du Christ mais en tant qu'épouse dévote, lectrice conventionnelle et émotive, ou en tant que femme instruite. L'essai montre ainsi que la formation de lectrice de Jane Grey est de nature politique, structurée par une série d'idées concernant l'église nationale, le statut de la femme, et les lois de succession héréditaire. C'est en réexaminant son œuvre et sa réception que nous pouvons comprendre dans quelle mesure l'idéologie politique avait un impact sur la nature de la lecture féminine dans l'Angleterre du début des temps modernes.

$\mathrm{L}$ ady Jane Grey Dudley's writings remain inconspicuous in the scholarship of early Norton Anthology of English Literature and her prominent role in sixteenth-century history. ${ }^{1}$ Although Carole Levin contributed an essay on Grey to Silent But for the Word (1985) - a formative contribution to the scholarship of early modern women's writing - there have been few subsequent studies of her work. ${ }^{2}$ When contemporary eyes are looking in Grey's direction, they still tend to focus on her biography, for she is, of course, England's infamous nine days queen. ${ }^{3}$ Even Levin uses Grey's writing primarily to illustrate the quality of her character, that she was "a strongly determined and articulate woman not afraid to speak out for what she believed."4 While apt enough, this approach does little to assess the historical engagements 
of Grey's writing, published first, posthumously and without publication details, in 1554 as An epistle of the Ladye Jane a righte vertuous woman, to a learned man of late falne from the truth of Gods most holy word, for fear of the worlde. This edition, possibly by John Day the evangelical printer of John Foxe's Actes and Monuments, was followed by another in the same year, also without publication details, entitled Here in this booke ye haue a godly epistle made by a faithful Christian A comunication betwene Fecknam and the Lady Jane Dudley. A letter that she wrote to her syster Lady Katherin. The ende of the Ladye Jane vpon the scaffolde. Ye shal haue also herein a godly prayer made by maister John Knokes. Three more seventeenth-century editions were printed under still a different title, The life, death and actions of the most chast, learned, and religious lady, the Lady Jane Gray. 5

Despite the mutability of their title pages, these volumes include the same texts, what the 1615 edition calls the "foure principall discourses": an epistle to a learned man fallen from the truth; a catechistical communication with Queen Mary's chaplain, John Feckenham; a letter to her sister Katherine; and Jane Grey's words on the scaffold. John Foxe adds three more texts to Grey's œuvre when he reprints the principle discourses in the Actes and Monuments along with "A letter of the Lady Jane sent unto her father," "A certayne effectuall prayer made by the Lady Jane, in the time of her trouble," and "Certayne prety verses written by the sayd Lady Jane with a pinne."6 Some of the principle discourses circulated in non-holographic manuscripts, as well as in print, and Jane Grey also famously wrote to her father and to the Master Lieutenant of the Tower, possibly John Brydges, in the margins of a manuscript collection of prayers.7

John N. King, whose scholarship displays a long-standing interest in Grey's writing, identifies the 1554 volume as "the most powerful contemporary Protestant attack on the Marian regime," but little more has been said of the issues pursued by the dialogue, scaffold speech, prayer, and epistles. ${ }^{8}$ Perhaps this is because Jane Grey does not quite fit within existing critical frameworks for women's writing. She is an exceptional figure, and not only because she was briefly a queen. She speaks from the conventional position of a woman about to die-acknowledged by Wendy Wall, Frances Dolan, Patricia Phillippy and others as a key space in which early modern women could fashion a public voice. ${ }^{9}$ Jane Grey's prose style, however, is unusually direct and confrontational. She does not produce work in traditionally literary genres; nor are the volumes printed under her name generically cohesive and textually stable. Despite neither publishing her works herself, nor relying only on writing to circulate her ideas - some of the texts purport to be records of oral exchanges-Jane Grey became a well-known author. Her story, her reading of the 
Bible, and her words, whether spoken on a scaffold or inscribed in a book, were not forgotten in the mists of history but iterated again and again in the centuries that followed as England continued to debate the legitimacy of female rule and the relative and sometimes competing merits of hereditary and Protestant succession.

This essay is an examination of Jane Grey as a reader, a woman who represents herself as a reader and who is afterwards regarded as the exemplary female reader. Grey was treated as a female exemplar from the sixteenth century onwards, for she was, as Carole Levin suggests, thought to be "beautiful, modest, deferential, quiet, and passive," qualities that typify ideal feminine behaviour in the early modern period. ${ }^{10}$ Jane Grey was also occasionally esteemed for qualities other than her deference and modesty, for some of her early modern admirers fixed on the strident devotion and vociferous godliness that she demonstrates in her writing. When these characterizations of Jane Grey persist in affording her the status of the good woman, they challenge ideological constructions of gendered behaviour that valued women only for beauty and preferred them to be submissive and exclusively domestic. Moreover, these divergent perspectives on Jane Grey's virtues, both personal and political, pivot on her reading. In her writings, their subsequent reprintings, and in the many retellings of her story throughout the early modern period, Grey appears as a reader - of the Bible, of prayers, and of Plato - but the methodology and significance of that reading changes alongside the presentation of her special virtues, with the result that Jane Grey illustrates how ideals of femininity and female reading respond to the pressures exerted by mutable political conditions. Jane Grey is a key figure through which early modern writers might articulate a position on the value of female governance, hereditary monarchy, and Protestant rule; representations of her reading, and consequently ideas of how women more generally should read, respond to these shifting political investments.

In addition to English histories, there are at least seventeen separate works about Grey-ballads, long narrative poems, epistolary love poems, romance novels, and stories for children-published between 1554 and 1800, many with multiple publications. ${ }^{11}$ The focus of this essay will be Jane Grey's writing and Tudor and Stuart commentaries about her. If Grey forges her identity as a reader against the backdrop of the religious and political conflict of the commencement of Mary's Catholic reign, subsequent representations of Jane Grey as a reader show how recurring political conflicts continue to foment depictions of her reading and that of women's reading more generally. Margaret Ferguson argues that "literacy is a social phenomenon surrounded and often constituted by interesting lies, as well as highly interested constructions of evidence on the part of writers from various 
historical eras including our own." For her, early modern discourses of nationalism, particularly the relationship between France and Britain, are a "second-order matrix for gendered theories and practices of literacy." 12 This essay argues that internal religious and gendered conflicts about governance constitute another of the matrices underpinning what counts as evidence of how women can and should read. Because Jane Grey was almost always regarded with approbation, because Jane Grey was so often treated as an exemplary woman, she becomes a key figure through which to understand the cultural formation of female reading. Ideas about female literacy were the outcome not only of a gendered contest within a patriarchal society that legally established women's subordinate place in schools, churches, and government, but also of a political struggle within those same institutions.

\section{'Dreadeful \& Feareful Sayings of God': Jane Grey's Writings in Print and Manuscript}

Jane Grey was the political pawn of powerful men. Under the influence of John Dudley, the Duke of Northumberland, young Edward VI named Jane his successor. She had been educated with the young king, as part of her parents' strategy to arrange a marriage between the two, but she was instead married to Northumberland's son, Guildford Dudley, on May 25, 1553. When Edward VI died on July 6, 1553, Northumberland and her father, the Duke of Suffolk, proclaimed her queen, but they proved unable to enforce the claim. Mary Tudor took power, Northumberland was taken into custody and executed, and Jane and Guildford Dudley were found guilty of treason after Suffolk rebelled with Sir Thomas Wyatt against Queen Mary's impending marriage to Philip of Spain. Jane Grey was beheaded inside the Tower of London on February 12, 1554. ${ }^{13}$ Despite being drawn into political events primarily as a marriageable virgin of convenient birth, Jane Grey's writing uses the language of Scripture and her identity as a reader of the Bible to fashion a polemical religiopolitical position that places her strategically and ethically in the political events in which she participated, however inadvertently.

In two of the four "principle discourses" printed in 1554, Jane Grey is straightforward and unrelenting in the rebuke of powerful and learned men. John Foxe identifies the learned man "fallen from the truth" as John Harding, chaplain to the Duke of Suffolk. ${ }^{14}$ Grey addresses the chaplain by calling to mind the "dreadful, \& feareful sayings of god," naming his sin in Biblical metaphors:

That thou, which some tyme wast the lively member of Christ: but now the defourmed impe of the divel, some time the beutiful temple of God: but now the stincking \& 
filthy kenell of Sathan, some tyme the unspotted spouse of Christe, but nowe the unshamefast paramour of Antichrist, sometyme my faithful brother: but now a straunger and Apostata. yea some tyme a stout christen souldier: but now a cowardly runawaye. ${ }^{15}$

These lines demonstrate John N. King's claim that Jane Grey employs the "plain style and manner of the gospellers" and the "characteristic voice of the Protestant preacher." ${ }^{16}$ According to Peter Auksi and Debora Shuger, the plain style was attached to anxieties about the conflicting obligations of faith and rhetoric and meant to have the effect of moving the audience to reform. ${ }^{17}$ With thoroughly unflattering Biblical similitudes, Grey makes the learned man's apostasy plain to him, speaking truth forcefully to move him to the Protestant faith. The "Christian plain style," as Auksi calls it, provides the rhetorical handbook for exceptionally confrontational female speech.

In addition to combating Catholicism, the language with which Jane Grey seeks to move her audience engenders conflict over presumptive male intellectual superiority. Jane Grey's "effectual” prayer, printed by Foxe, openly contemplates the relationship between militant faith and gender roles. Grey acknowledges she is a "poore and desolate woman," but concludes she is also "thy workmanship created in Christ Jesus." As a result, she can pray:

Onely in the meane time arme me I beseech thee, with thy armour, that I may stand fast, my loynes being girded about with veritie, having on the brest plate of righteousness, \& shod with the shoes prepared by the Gospell of peace, above all thinges taking to me the shield of fayth, wherewith I may be able to quench all the fiery dartes of the wicked, and taking the helmet of salvation \& the sword of the spirit, which is thy most holy word: praying alwaies with al maner of praier \& supplication that I may refer my selfe wholy to thy wil. ${ }^{18}$

With the language of Ephesians 6, Jane Grey fashions herself as a warrior reader who, Bible in hand and submissive only to God, vanquishes all enemies. Grey's letter to the apostate learned man figures him as effeminate and sexually corrupt in his faith and in his approach to reading. As a worshipper of the "whoore of Babilon," as well as a cowardly runaway and a paramour of the Antichrist, this scholar is entirely the wrong kind of man. ${ }^{19}$ John N. King highlights how gendered antithesis is characteristic of Reformation writing, as in John Bale's Image of Both Churches, which represents truth and falsehood in the language of female virtue and vice- the church as virgin or whore. ${ }^{20}$ Grey questions the learned man's masculinity, a more aggressive use of gendered metaphors. Instead of being a "white hewred milke soppe," the learned man should use the "two edged sword of gods holy word," "fight manfully, come 
lyfe, come death," and so return again into "Christes warre." ${ }^{21}$ The ideal Christian is the "stout christen souldier," and Jane Grey proves fully capable of combat. She triumphantly wields the Bible as a weapon of confrontation, division, and redemption and fulfills in herself the militaristic ideal of faith she holds up as a mirror for the apostate man. By using masculine metaphors to figure the power and appeal of Protestantism, Grey reinforces the dichotomy between femininity conventionally understood as weakness and masculinity as strength. But the rhetorical presentation of militant Protestantism as masculine and Jane Grey as its defender ensures that masculinity is not the exclusive preserve of men.

The catechistical debate with John Feckenham, Mary's chaplain, even more precisely scripts the doctrinal triumph of a militant Protestant woman over an enfeebled Catholic man. As in the letter to the learned man, religious conflict mitigates expected codes of gendered decorum. In the dialogue with Feckenham, Jane Grey grounds her speech in the language of Bible and represents herself as its superior reader. If this time her language is less astringent, the dialogue proves she is a better reader than he, despite his presumed social privilege as a learned man. When she asks Feckenham which scripture states that there are seven sacraments, he evasively responds "Well, we will talke thereof hereafter." When Feckenham accuses her of basing her faith on authors "as say \& unsay, both with a breathe, \& not upon the church," Grey insists, "No, I ground my faith upon gods word, \& not upon the church" because the good church will be tried only by God's word and not by tradition. ${ }^{22}$ While recognizing the authority afforded to a man who is the representative of the queen, of institutional religion, and of scholarly learning, Grey does not submit to it on spiritual matters but confronts directly the foundations of Feckenham's faith.

In these debates, Jane Grey's divisive rhetoric and her strategic use of the Bible depend upon a context where it is considered acceptable to dismiss theological alternatives, radically and vehemently, and culturally productive to perform that debate on a public stage. Jane Grey's work was written and appeared at an historical moment, when, as happened in 1551, conservative theologians could be brought from prison at the behest of Secretary Cecil to lose a public debate on the Eucharist to Cambridge theologians. ${ }^{23}$ Jane Grey, too, debates Catholic scholars, but the resulting theological contest, in addition to performing a Protestant triumph of truth, also occasions the reversal of gender hierarchy. The Protestant woman must defeat her Catholic opponent, even if he is a man, a scholar, or a priest; men are not assured a social position of superior intellectual authority on the grounds of their sex when they deal with Protestant women. Even in interactions with Protestant men, faith can 
compel the transgression of conventional gender hierarchy. A 1553 letter, originally in Latin, from Grey to Heinrich Bullinger ponders the implications of her resolute prayers on his behalf. She wonders that she might "display more boldness than prudence" in them, but asks that he "pardon the more than feminine boldness of an untaught virgin, who presumes to write to a man, and one too who is a father in learning." ${ }^{4}$ Despite her "age, sex, and moderate attainments in literature," she must write, she says, because of respect for his virtue, character, and favour. She fashions her confidence from morality and, surely, too (if this is unacknowledged) from the aristocratic family and education that gave her access to prominent theologians who are of a lower social status than she is.

By the nineteenth century, Grey's boldness needs justification. As Nicholas Nicolas explains in his 1825 biography and edition of her works, some have doubted that the letter to the learned man could be the genuine production of Jane Grey, "on account of the intemperate, and indeed vulgar epithets which it contains;" the "coarseness of its language is not consonant to the gentleness and delicacy which we attribute to her disposition." Jane Grey's style simply does not accord with nineteenth-century conceptions of feminine decorum and of Grey's exemplary character, and so Nicolas attributes her style to the vagaries of history-the "common weapons of the reformers of the day" - and to Biblical sources. ${ }^{25}$ Setting aside his assumption that the moral woman will necessarily be demure, part of Nicolas's point remains apt: the English Reformation did produce and legitimate female literacy and ensure that silence and submission to the directives of men were not the only imaginable feminine virtues. This is not to say that a commitment to literacy was an exclusively Protestant virtue, for Catholic women were also readers. ${ }^{26}$ The key point is that in the highly divisive religious conflict of the 1550 , the ideal woman could be a warrior if she was a reader; and combative speech, even by women against educated men, could be acceptable in print, even necessary when the subject matter was faith.

With her letter to her sister Katherine, Jane Grey takes her gendered theological triumphalism and investment in reading in a different direction. Not concerned with defeating the Catholic scholar, this letter seeks to ensure the spiritual enfranchisement of a woman. Tellingly, the epistle is written in the Bible itself, "in the ende of the New Testament in Greke," and begins by reflecting on the book: "I have here sent you good sister Katerine, a booke: which although it be not outwardly trimmed with gold, yet inwardli it is worth more the[n] precious stones." Grey figures the book as a visible metaphor for the book's message: truth belongs not to the powerful but to the simple, the reformed who are devoted to the Bible alone and not to institutionalized church tradition. In addition to adopting this typically reformist 
position, Grey figures reading as a weapon for her sister to deploy in the problem of her patrimony. The sisters are, after all, able to exchange a Bible in Greek, a material metaphor, if unmentioned, of their privileged aristocratic upbringing. As a sword, the Bible can strike at patriarchal property law:

It is the boke (deare Sister) of the Lawe of the Lorde. It is his testament and last will, which he bequested unto us wretches, which shall leade you to the path of eternall joye. [.. I It shal Winne you more, then you should have gained by the possession of your woful fathers lands. For if God had prospered him you should have inherited his la[n]des: so if you appli diligently this boke, seking to direct your life after it, you shalbe an inheritour of sutche riches, as neither the covetous shal withdraw from you, nether the theife shal steale, neither yet the mothes corrupte. ${ }^{27}$

Because the Duke had no male heirs, Katherine Grey would have received a great inheritance - a rare enough occurrence for a woman - but as a result of his participation in the Wyatt rebellion, the estate of the Duke of Suffolk was attainted and his wealth forfeit. ${ }^{28}$ Although acts of attainder were frequently reversed, Jane Grey's remedy for her sister's inheritance woes is spiritual rather than temporal. ${ }^{29}$ Yet the legal metaphor of the will figures reading as an activity with legal consequences. The Bible is a law superseding that which governs and disinherits Katherine-a strategic, legalistic use of scripture akin to the confrontation Paula McQuade has observed between Anne Askew and her inquisitors. ${ }^{30}$

Jane Grey's speech on the scaffold is her final performance of her identity as a reader and a Protestant subject in a Catholic state. The first 1554 edition prints the speech alone, but subsequent editions add a report of her procession to the scaffold, details that enhance Grey's identity as a woman of the book. The second 1554 edition couples Grey's original protestation that she was innocent of treason to the observation that she wrings her hands, "in which she had her booke." The editor supplements her confession of having neglected the word of God and of loving herself and the world with a report that she said the "psalm of misereri mei Deus in English" and gave her gloves and handkerchief to her maid Mistress Tylney and "her booke" to "Maistre Thomas Brydges, the Lyuetenantes brother." ${ }^{1}$ These same details appear in another early account of Grey's death, Harley MS 194, "a pocket diary extending from July 1553-1554," which provides a source for the sixteenth-century accounts of Grey's death written by Holinshed and Stowe. ${ }^{32}$ The diarist adds still more books to Jane Grey's story. As she walked to Guildhall to be arraigned, the diarist says, she wore "a blacke gowne of cloth, tourned downe; the cappe lyned with fese velvett, and edget about with the same, in a French hoode, all black, with a black byllyment," and carried two books, "a black velvet boke hanging 
before hir, and another boke in hir hande open;" later, she walked to the scaffold with a "boke in hir hande, wheron she praied all the way till she cam to the saide scaffolde, wheron when she was mounted, \&c."33 In these historical accounts, Grey uses books as stage properties. Publicly reading them facilitates the externalization of her inward commitment to the Bible, just as writing does. Those who record the details recognize the significance of the performance. Frances Dolan has argued with regard to such moments of public death that "women are constituted as subjects who think, speak, and act on the condition that they are represented as transcending bodily suffering and death." 34 This paradox is evident in Grey's death, too. Even as she stoically dies, she is scripting the scenes in which she appears and using the moment of autonomous agency and visibility her death affords her to testify to her identity as a reader, woman, and political subject.

Grey is simultaneously a Protestant devotee of the vernacular Bible-a resistant stance with regard to England's national religion — and a faithful English subject who submits to queen and executioner. The book held in her hand as she walks to the scaffold makes visible her prayers, otherwise undetectable within the recesses of her mind; that same book ultimately grounds and authorizes her public speech. She reads prayers before she speaks to the people, and she draws attention to the book again while she is speaking. Reciting the Psalm in English makes clear that she is a Protestant reader of the vernacular Bible, for Psalm translations were controversial, while giving the book away seems at once a token of her forgiveness of her executioners, her acquiescence to Mary's royal authority, and her persistent, even evangelical, resistance to their Catholicism. With her books, Jane Grey performs the political position identified in Thomas Cranmer's exhortation on obedience in the book of homilies legislated for use in all churches during the reign of Edward VI. ${ }^{35}$ Cranmer allows that monarchs commanding what is contrary to God's commandments should not be obeyed, but because they are God's anointed, subjects should never resist violently nor rebel but "paciently suffre al wronges and injuries referryng the judgemente of our cause, onlye to God." ${ }^{6} 6$ Thus does Jane Grey resist the queen's faith but accept her authority, a distinction that retains the capacity to highlight the imperfection of earthly law. Grey has access to traditional sources of power, for she is the daughter of a duke, reads the Bible in Greek, and writes letters in Latin. These matter, for this social authority must underpin not only the conditions that enable her to learn to read and write but also those which have placed her in the public sphere, on the throne, in prison, and on the scaffold. That said, her words and her performance construe female reading as authoritative, true, and autonomous. She need not defer to scholarly unreformed men to derive meaning from what she 
reads. In this, she represents a possibility, for these qualities, needless to say, are not standard in contemporary depictions of early modern women's reading, which so often fixated on ensuring female chastity and patriarchal, institutional control over female thought. ${ }^{37}$ However, such restrictive theoretical dictates are, in practice, insensible of other social structures, especially class hierarchies that afforded aristocratic women power over some men and of institutionalized doctrinal conflicts between men themselves. At an advantage in this context, Jane Grey can use the Protestant imperatives to read the Bible and to reject heresy to challenge masculine intellectual authority, the legitimacy of patriarchal legal tradition, and the exclusion of women from being political subjects.

Harley MS 2342, a manuscript prayer book, concretely illustrates the important relationship between reading and writing in Jane Grey's writing, even as it further develops her political position by distinguishing it from that of her father. In the margins of the prayer book's pages, Jane Grey writes to the Duke of Suffolk and the Master Lieutenant, juxtaposing the epistles and prayers to political effect. Like the Greek testament, the manuscript prayer book is a materially meaningful and symbolic gift in which Grey's inscriptions reflect on the words already contained on its pages. The small vellum manuscript is a collection of occasional prayers in a neat calligraphic hand, many of which seem especially apt for Jane Grey's situation. The manuscript includes a prayer based on Psalm 51, the psalm she apparently recited on the scaffold, along with prayers for patience, forgiveness, wisdom, and facing adversity. The Harleian Manuscript Catalogue suggests that the manuscript belonged first to the Duke of Somerset, but prayers imaginatively placed in the mouths of women powerful in their faith and in their ability to defend themselves and their nation might just as well suggest the manual was produced with a woman in mind.$^{3}$ In any case, they make clear that it was possible to imagine in the $1550 \mathrm{~s}$ that female fortitude in faith might have substantial political consequence. The prayer of Queen Esther "for help agaynst her Enymyes," and that of Judith "for the ye victorie of Olyffernes" are the prayers of faithful women who save their people, even with literal swords in their hands. That of "Sara ye doughtr of Raguell whan she was slaudred" is the prayer of a woman accused of corruption after marrying seven husbands who were killed by an evil spirit; God gives her a husband, thus confirming her chastity. ${ }^{39}$ In reading these prayers, Jane Grey has access to the voice of the "poor" woman she identified within the "effectual" prayer printed by Foxe-a woman who is nevertheless confident of a divine response because of God's special relationship to her and to his people. ${ }^{\circ}$ By writing in this particular book, Jane Grey identifies herself as a reader of devotional prayers and colours her words in the hues 
of a triumphalist faith that allows that victory even to women, heroines whose faith, militancy, and chastity are affirmed by God.

Jane Grey's holograph letter to the Master Lieutenant is beneath several pages of a prayer called the "Song of Austeyn and Ambrose," a poem of praise celebrating the holiness and saving power of a God who "didest not abhore the virgenes wombe." 41 She writes: "Forasmuche as you have desired so simple a woman to wrighte in so worthy a booke, gode Mayster Lieutenante, therefore, I shall, as a frende desyre you, and as a Christian require you, to call uppon God, to encline youre harte to his lawes, to quicken you in his waye, and not to take the worde of trewethe utterlye oute of youre mouthe." 42 As in Grey's other representations of her relationship to powerful men, evangelical imperatives override those of gendered deference: despite being a simple woman, she must write to encourage the master lieutenant to know the Bible. Moreover, Grey juxtaposes her hectoring, reformist inscription with a prayer that asserts that "The faire fellowshippe of marteres praise the." 43 She does not openly dispute the lieutenant's earthly authority but contests his theological attachments, and with the placement of her words claims a place in a community of martyrs who see the Bible and not worldly governors as the source of the true law. Although Grey is not being executed for heresy, the presentation of the prayer book, like the gift of the New Testament to her sister, claims for the Protestant authority of the true law while submitting her to the false authority of the earthly monarch.

As a woman, of course, Grey is not meant to be a political subject, but a daughter and a wife covered by the authority of her father and husband. Writing in the prayer book, Grey articulates an inward subjectivity disentangled from this subordination. She writes to the Duke of Suffolk in the bottom margins of pages containing a prayer entitled "Saynt Jerome devocion Oute of Davyd Saulter." Her inscription begins by figuring the Bible as the only legitimate consolation:

The lorde comforte your Grace, and that in his worde whearein alle creatures onlye are to be comforted. And thoughe it hath pleased God to take awaye ii of youre children yet thincke not, I most humblye beseche youre grace, that you have loste them but truste that we by leacing this mortall lyfe, have wunne an immortal life and I for my parte, as I have honoured youre grace in thys life, wyll praye for you in another life. youre gracys humble daughter Jane Duddeley. 44

While her words express filial submission with the reassurance that she has won immortal life, the prayer above them asks that God will "hyde me as though I were under the shadowe of thy wynges;" on the page where her signature appears, the prayer asks that God will remember not "the synnes of my youth." 45 Guildford Dudley, too, writes to his father in the margins of the prayer book to recommend 
himself as an obedient son. Yet like his wife, he places his letter adjacent to a prayer with a different message. The prayer asks for deliverance from death and praises God for saving the "Children of Israel from [the] Red Sea" and "Children from the furnace of burning fire." 46 The conjunction of reading and writing gathers to their words a level of moral irony, for they write to fathers who not only failed to protect them but involved them, in their youth, in the sin of treason. Grey's critique is made still more explicitly in a letter to her father included in Foxe's Actes and Monuments, which begins: "Father, although it hath pleased God to hasten my death by you, by whome my life should rather have bene lengthened $[\ldots] . " 47$ Intricately connected, reading and writing communicate Jane Grey's autonomous religio-political position. She is not simply meek and obedient to her paternal and political masters; her husband certainly never appears in the prayer book as one with any authority over her but simply as his father's son, another descendant of a rebellious father. Jane Grey's inscriptions and their placement, her writing and reading, suggest that spiritual loyalties supersede the earthly-whether to laws, to religious institutions, or to fathers.

In her own writing, Jane Grey's identity as a reader is doubly politicized. In the first place, Jane Grey's reading is obviously invested in structures of power by her involvement in a succession crisis. If the ostensible purpose of her reign was to guarantee the Protestant identity of England, Grey's own identity as a loyal English subject and Christian were compromised by having been made queen at the expense of hereditary succession as it was established in Henry VIII's will. She repeatedly and consistently uses her writing and her representation and performances of reading — in debates, in writing, and on the scaffold — to forge a political identity in which she is both Christian and faithful English subject: a Protestant faithful to the truth but submissive to royal authority, in alignment with the view that obedience is a necessary condition of spiritual knowledge. In the second place, when Jane Grey advocates reading the Bible, she identifies herself with a Protestant community. This, too, is political. Indeed, Kevin Sharpe has argued that "[r]eading, the act of interpreting, mediating, and personalising texts, cannot be, and in early modern England was not, separated from the structures of hierarchy and authority."48 In mid-sixteenth-century England, writing about reading is identity politics, a way of marking one's loyalty to a faith that was challenging traditional practices around who should read and why. As Christopher Haigh says, "Protestants were readers; that was what their leaders expected, and that was how their enemies identified them: 'heretics and two-penny book men." 49 
Questions of who might be allowed to read and how, of who might produce authoritative meanings, and of the place of Bible reading in the development of faith were disputed at the highest levels. Henry VIII had instituted in 1543 the Act for the Advancement of True Religion, which forbade men below the rank of yeoman and women from reading the Bible privately or publicly, with the caveat that noblewomen and gentlewomen could read by themselves, but not to others..$^{\circ}$ Edward VI, on the other hand, repealed the Six Articles of 1539 (which legislated communion without both bread and wine, private masses, the celibacy of priests, auricular confession, and the doctrine of transubstantiation) and the Act for the Advancement of True Religion; penalties imposed in 1543 for printing, selling, or possessing the Bible in English were abolished, and more Bibles were printed. Thomas Cranmer's Certain sermons or homilies appointed to be read in churches begins, after all, with "A Fruicteful exhortation, to the readyng and knoweledge of holie Scripture," which makes reading central to knowledge of God..$^{11}$ The reformed church building replaced images with words, painted in plaster and on whitewashed walls, which made the church interior, as Diarmaid McCulloch puts it, into a "giant scrapbook of scripture." $5^{2}$ During Jane Grey's lifetime and after, Bible reading was inherently political, determined as it was by power relations structured by class, gender, education, and factional loyalties. ${ }^{53}$

With her words and her appearance on the scaffold, Jane Grey demonstrated that she was alive to the politics of Bible reading. She is like other female martyrs studied by Megan L. Hickerson, Carole Levin, Christine Peters, Jennifer Summit, Diane Watt, and me. Martyrs could provide models of chaste femininity and divinely inspired vehemence, and their authority, based not on traditional theological education but on Scripture alone, could be used to contest the political order. ${ }^{54}$ Jane Grey is not alone in this, but her works do need to be better recognized. She is the author of texts in which reading the Bible provides a language and a style in which to speak and write, the authority for the textual production, and, with direct advocacy for reading, a substantial component of its content. With her writing, she fashioned a Protestant identity that inflected religious change with a challenge to gendered structures of power.

\section{Jane Grey's Writing During the Reformation: The Matchless Strength of the Weaker Sex}

The female reader was, according to Marsha S. Robinson, “an icon exemplifying the seminal importance of the inclusive Protestant doctrine of the priesthood of 
all believers." 55 Jane Grey becomes one of these exemplary female readers for her Protestant contemporaries, but the methodology with which she reads and its verbal and political consequences are in tension with other political circumstances. Early modern literary narratives of her life, her education and marriage, her ascent to the throne, and her execution in the Tower nearly always mention how and what she reads. This can be attributed to Grey's own writings, which continued to be available, to her use of books as writing tablets, to her presentation of a book on the scaffold, and to Roger Ascham's famous observations of her in his Scholemaster. Grey, he said, read Plato's Phaedon in Greek "with as moch delite, as som ientleman wold read a merie tale in Bocase." ${ }^{56}$ But depending on the writer's political stance, Jane Grey could epitomize militant, combative, verbalized reading or that which was compliant and quietly devout.

In the sixteenth century, Jane Grey's writings were taken up in large part as they first appeared in the volume of 1554; her militancy was useful. Protestant writers like John Knox, Miles Coverdale, and, of course, John Foxe associated themselves with her texts or reprinted them in their own publications. The second 1554 edition, Here in this booke ye haue a godly epistle made by a faithful Christian, concludes with a prayer by John Knox, who asks that God "take not from us the light of thy gospel and suffer no papistry to prevaile in this realm. Illumynate the hert of our sovereigne Lady Queene Mary with pregnaunt gyftes of the holy goste and inflame the hertes of her gracious counsailes with thy true feare and love and remove from al hertes the contempt at thy worde." 57 Despite Knox's well-known vilification of female rule, he was the recipient of the patronage of the Duke of Northumberland, which may help to explain the match..$^{8}$ The placement of Knox's prayer after Jane Grey's texts invites comparison between Queen Mary and Jane Grey. Her commitment to reading and the word, the inflamed heart manifestly evident in her texts, indicts the queen's theological failures. ${ }^{59}$

Miles Coverdale's translation of Otto Werdmüller's A moste frutefull, piththye and learned treatise, how a christen $m a[n]$ ought to behaue himself in the dau[n]ger of death, printed in 1555 in Wesel where there was a small community of English Protestants, reprints the letter to Katherine (a volume printed again in 1574 and 1595). ${ }^{60}$ Coverdale also includes Jane Grey's letter to her sister in his collection of letters by martyrs, the only one by a woman in Certaine most godly, fruitful, and comfortable letters of such true Saintes and holy Martyrs of God (1564) ${ }^{61}$ For Coverdale, such letters are evidentiary: "it doth us good to read and heare, not the lying legendes of fayned, false, counterfayted, and popish canonized saincts, [ ... ] but such true, holy, \& approved histories, monuments, orations, epistles \& letters, as do set 
forth unto us ye blessed behaviour of gods dear servauntes." ${ }^{\text {"2 }}$ Coverdale uses Jane Grey's own words, those inscribed in her talismanic and tragic Greek testament, to counteract the stories of Catholic saints and powerfully to document the historical truth of the reformed religion. Protestants were in need of precedents to authorize their rejection of tradition. Jane Grey's letter provides evidence of the truth of the reformed gospel. Because women are the weaker sex, they read, speak, and hold to their beliefs in the face of adversity not because they are strong or learned or powerful but, self-evidently, because God is on their side; without divine aid, women would not be able to stand in their faith. ${ }^{63}$

Given the political, national, and religious consequence of the encyclopedic and popular Actes and Monuments, John Foxe is surely the most significant purveyor of Jane Grey's writing in early modern England. In addition to the folio printings of the complete Book of Martyrs, there were several popular abridgements which included some or all of Jane Grey's texts. ${ }^{64}$ Perhaps not surprisingly, Foxe is not just reprinting Grey's works but negotiating her gendered religious and political identity - a concern for Jane Grey, too, although Foxe makes a number of small but significant changes to her texts. He underscores her words with marginal notations detailing their Scriptural source. He adds Latin epitaphs in her praise by Laurence Humphrey and John Parkhurst, members of his circle in exile. ${ }^{65} \mathrm{He}$ also adds a Latin poem, a "pretty verse" written by Lady Jane with a pin. The Latin testifies to her humanist education, while the fact that it was made with a pin might align her with other martyrs. John N. King draws attention to other entries in Actes and Monuments written with exotic writing materials, as a result of imprisonment and denial of access to paper, pen and ink. ${ }^{66}$ Together these additions enhance her authority and her identity as a martyr, despite the fact that Grey was executed for political reasons rather than for her religious beliefs.

Other alterations disengage her from her political position as erstwhile queen. Foxe does not, for instance, reprint the proclamation of Jane's claim to the throne, although it was certainly available to $\mathrm{him} ;{ }^{67}$ nor does he print the letters to the Marquis of Northampton, the Sheriff and others in Surrey, and to Sir John Bridges and Sir Nicolas Poyntz that also survive in manuscript copies ${ }^{68}$ Consequently, Jane Grey does not appear in Foxe's work arguing that she is legally queen of England. To the dialogue with Feckenham printed in 1554, Foxe adds introductory and concluding speeches by Jane and Feckenham. He deplores Jane's position and tells her he comes from the queen to influence her to the truth; Jane welcomes Feckenham if he brings consolation, asserts that she little laments her situation, thanks the queen for her attention to "her humble subject," and encourages Feckenham to do 
his duty towards the queen in attempting to convert her. At the end of the dialogue, Feckenham reemphasizes his pity for Jane, while she encourages him to turn to God. ${ }^{69}$ These alterations add emphasis to Grey's presentation of herself as at once obedient to the queen's legal authority and resistant to her attempts to convert her, which are against God's law. The letter to her father, another addition by Foxe, sees Grey further explain her political stance:

And yet though I must needes acknowledge, that being constrayned, and, as you wot well inough, continually assayed, in taking upon me I seemed to consent, and therein greevously offended the Queene and her lawes: yet do I assuredly trust that this mine offence towards God is so much the lesse, in that being in so royall estates as I was, mine enforced honour being never with mine innocent hart. ${ }^{\circ}$

Grey positions herself as a political subject obedient to both God and monarch. She has offended the queen because of seeming to consent to take the crown, but she has not offended God because he knows, beyond merely what seems, her innocent heart.

Female agency has been an ongoing critical concern in studies of Actes and Monuments and Protestant reform: what happens if women, who are typically expected to be silent and obedient, resist the direction of Catholic interrogators or husbands, and even speak boldly in the name of faith? The resulting strain on ideals of femininity, as critics show, can play out in a variety of ways, depending on the origin and genre of the martyr narrative in Foxe's work, editorial influence by Foxe and others, and the class and marital status of the woman involved; critics also note differences between how printed narratives imagine the function of gender and how they were read by female readers. ${ }^{71}$ In Jane Grey's case, Foxe's alterations to the earlier editions of her work amplify her expressions of obedience to father and queen. Yet Jane Grey explicitly defines the problem for herself. Her works are reprinted, and they share with Foxe a concern with reading, for Foxe sought to shape a Protestant community with a consistent set of reading practices and coherent interpretations..$^{72}$ The attitude towards obedience that Grey expresses is complex. The words Foxe prints do not suggest simple feminine acquiescence. When she writes to her father to explain her relationship to the queen and refers to the doctrine of coverture, she distinguishes between outward and inward action, as Tudor treason laws themselves did. G.R. Elton and Jonathan Van Patten explain that English treason law, grounded in the definition of treason in the 1352 Statute of Treason, traditionally distinguished between treasonous thoughts and actions, punishing only the latter. Henry VIII added to the treason law treasons committed by printing or writing, verbal attacks on the king, including calling him a heretic 
or a usurper to the crown, and attempting to subvert the order of succession; in 1547, Somerset got rid of some of the treasons but kept the law against treasonous words. ${ }^{73}$ Not confessing to treasonous thoughts, Grey confesses only to having acted treasonously. She at once abjures independent political agency and culpability (she did not act of her own inward volition, because she was outwardly constrained by her father), and defines its possibilities (she might have acted with inward ascent, if she did not). She is capable of political action, but she did not undertake it in this instance where she was only acting upon filial obedience. She is guilty of treasonous action as the law defines it, but if the law could search the human heart, she would be found innocent. Because Foxe requires for his narrative a virtuous woman who acted with different motives than her father and father-in-law, Jane Grey appears on the pages of his work as an autonomous political subject.

In addition to being linked to Knox, Coverdale, and Foxe, Jane Grey is taken up by others in the sixteenth and seventeenth centuries, in editions which want slightly different things of her words but remain invested in her power and assertiveness and not exclusively in her role as victim. The four principle texts appear in The Life, Death and Actions of the Most Chast, learned, and Religious Lady, the Lady Jane Gray, Daughter to the Duke of Suffolk, printed in 1615, 1626, and 1636. These editions use Jane Grey's texts to confront the Stuart church, for they are printed according to its editor "to awaken the sleepie world from her fantasticke Lethargie, to behold in that, which we call the weaker sexe a strength matchlesse and invincible." The letter to her sister signals her virtuous industry and thrift. Not one to waste, Grey employs the blank pages in her new testament to "incit[e] her zeale to some good and charitable office.”74 Jane Grey's energetic femininity indicts those less fervent in their faith, especially shaming those not of the weaker sex. Jane Grey's polemical style remains acceptable, her identity as a reader aligned with fortitude and learning. After 1636, independent editions of Jane Grey's works become less available, but they continue to appear in a few other collections and in Foxe's Actes and Monuments, which gives them a continuing place in religious culture, but a place more aligned with Foxe's own fortunes. ${ }^{75}$

\section{Jane Grey in Literature: From Conquered World to Empress}

The remainder of this essay will explore how Jane Grey's identity as a reader-and by extension women's reading, given Grey's status as an exemplary female-appears in plays and poems that represent her life and words. These, like the varied editions of Jane Grey's own texts, were politicized not just by changing perceptions of the 
social place of women but also by questions of national governance. During the Tudor and Stuart period, Jane Grey stories tend to reflect on female political power, supporting it during Elizabeth's reign and disavowing it during James's. ${ }^{76}$ According to Carole Levin, Elizabeth herself never turned to Jane Grey as an exemplar, but others certainly saw her as Elizabeth's virtuous Protestant predecessor. ${ }^{77} \mathrm{Mi}$ chael Drayton's Englands Heroicall Epistles (1597) follows the tack taken by Ulpian Fulwell's The Flower of Fame (1575), which prints two poems, "A Commemoration of Queene Jane" and “An Epitaph on the death of Queene Jane." Fulwell presents Jane as having "a Matrons hart,/with modest mynde most meeke" in order to prove that England has women, like Jane Grey, Anne Boleyn, and Katherine Parr, equal to Rome's great ladies. ${ }^{78}$ Thomas Bentley's Monument of Matrones (1582) reprints Jane Grey's own words - the “effectual prayer," the letter to Katherine, the Latin verses written with a pin, and her last eight words (a radically abbreviated version of her speech on the scaffold) - to similar ends. They aid Bentley in appealing to Elizabeth for patronage, in proving God's special favour to England in peopling her with virtuous women, and in providing a pattern of piety for English women. ${ }^{79}$ Drayton's collection of epistolary poems includes a fictional exchange between Jane Grey and her husband and presents Grey as precedent for and embodiment of England's commitment to Protestant queens. Drayton's Grey is a writer, but she writes not as a triumphant Christian but as a weeping woman, with her tears transfigured into ink, her writing into mourners - a motif that would be taken up in the eighteenth century in the Ovidian epistles written in Jane Grey's voice. ${ }^{80}$ Although this Jane Grey is not much of a Christian soldier, she is a queen, prescient and politically concerned in her death; she knows that Mary will produce no heirs and that she will leave the throne to Elizabeth, "which broken, hurt, and wounded, shall receave it." ${ }^{81}$ In a poem that does not question the legitimacy of female rule, Grey is also a learned reader, for Drayton's Guildford Dudley tells his wife that "a Crowne should have becom'd thee well,/Mee thinks thy wisedome was ordain'd alone,/To blesse a scepter, beautifie a throne." To justify with reference to her intelligence Jane's personal fitness for the throne is to legitimate and naturalize female rule. These lines are further substantiated in Drayton's gloss, which reports from the chronicles: "Sildome hath it ever beene knowne of any woman endued with such wonderfull gifts, as was this Lady, both for her wisedome and learning, of whose skill in the tongues one reporteth by this Epigram [here Drayton repeats one of the lines of poems of praise from Foxe's Actes and Monuments]." ${ }^{82}$ Although Drayton's Jane Grey is no longer excoriating, she remains a reader with a humanist education and is thus capable of rule as a learned, Protestant woman. 
The Famous History of Sir Thomas Wyat (1607), on the other hand, removes Jane Grey from any political involvements, with a contingent redrawing of the purpose of Jane Grey's reading. The virtuous woman, who lives a private life, reads to different ends than the man who governs. John Webster and Thomas Dekker (and likely others) base the play on the works of Foxe, Grafton, Stow and Holinshed, and it is probably an abridgement of two Lady Jane plays (the "playe called Ladye Jane" for which there are several records of payment in Henslowe's diary in 1602). ${ }^{83}$ The action of Sir Thomas Wyat runs from the death of Edward VI to the execution of Sir Thomas Wyatt, and dislodges Jane Grey as the eponymous central character. Yet she remains to insist on the imperatives of hereditary succession structured according to Henry VIII's will and to link female virtue to domesticity. Thus, when Suffolk and Northumberland declare Jane queen, she tells Guildford she does "injoy a Kingdome having thee" (1.2.15). Together the pair assert that she is a usurper, for as Jane says, "Were this rightly scand/Wee scarce should find a King in any Land" $(1.2 .31,32)$. Jane infers a general principle of strict hereditary succession from the purported illegitimacy of her own claim and ties her position not just to political tradition but to her preferred identity as a wife.

The Famous History of Sir Thomas Wyat emphasizes the link between compulsory female domesticity and reading with invidious comparisons between the subordinate Jane and the ambitious Mary.Jane has married an English man (3.1.130-136), and she is willing to entirely eschew power, for she is happy to "leave a Queenes, and keepe a Ladies name," to be "pure within, and mildly chast without" $(1.6 .92,105) .{ }^{84}$ Jane's reading merely embellishes this wifely devotion. Queen Mary attempts to use the iconography of the book to enhance her power and makes her first entrance with "a Prayer Booke in her hand, like a Nun" (1.3), but only Jane's reading is legitimate. She reads not as the Catholic nun but as the Protestant wife, a status to which she adds the identity of martyr as both Guildford and Jane die with books at hand:

Jane. The last good morrow my sweete love to thee.

Guil. What were you reading?

Jane. On a prayer booke.

Guil. Trust me so was I, wee hade need to praye,

For see, the Ministers of death drawe neere. (5.2.45-49)

The play's Jane is modeling, as Marsha Robinson suggests, "the art of dying," but the authors are also surrounding female reading with a domestic, devotional purpose directed by a husband. ${ }^{85}$ This way of reading is critical to her status as a good woman. Other parts of the play similarly disengage Jane from the public realm. She is not allowed her speech on the scaffold. Nor does she see the headless body of her 
husband and heroically continue in her prayer book on her way to the scaffold, for Jane is, exceptionally and ahistorically, executed first. As a result, Guildford blazons her disembodied head and the dead Jane becomes a necrophilic version of the conventional love object: "A ruddie lippe, a cleere reflecting eye,/Cheekes purer then the Maiden oreant perle,/That sprinckles bashfulnes through the clowdes" (5.2.164-166). Unlike Queen Elizabeth, who manipulates these conventions of Petrarchan display to govern, the play's Jane is utterly powerless, and her beauty affords her no sway. The good woman is a wife and all her actions, including reading, are directed to domestic, and not political, ends. This is a doctrine well-suited to the masculinist and homosocial court of James I. ${ }^{86}$

In the late seventeenth and early eighteenth centuries, the succession conflicts of the late Stuart court produced another spate of Jane Grey publications. 1688 saw the publication of the anonymous broadside A Conference Between the Lady Jane Grey and F. Fecknam, which seems to be based on the histories of Heylyn, Holinshed, and Foxe and includes some of Grey's own texts along with a purported speech, reported only by Heylyn, in which Grey uses her reading as the authority for refusing the crown. "Licensed according to Order. 1688," the broadside queries the legitimacy of replacing the hereditary, if Catholic, monarch with a Protestant who has a more distant claim to the throne. ${ }^{87}$ John Banks's The Innocent Usurper; or, The death of the Lady Jane Gray. A tragedy (1694) constructs Jane Grey and her reading within a play informed by the same political commitments. This play was first printed anonymously and then again posthumously when it was renamed as The Tragedy of the Lady Jane Grey in 1715, a year in which there was a Jacobite rising, and in 1729. The preface asserts that the play was written ten years before its publication, but the factuality of the claim might be drawn into question, since it appears as part of a rebuttal to criticism of the play, which apparently could not be performed. As the preface explains, it was "by a Capricio and Hardheartedness of some of the Civil Powers of the Stage, like an Infectious Offspring, carry'd back to the Place of its Birth." 88 Whether the problem was that the play's wicked Mary might be likened to her co-religionist James II, or Jane, a usurper, to William I and Mary II (the play was published in 1694, the year of Queen Mary II's death) is difficult to say. What is clear is that the play employs female characters and Jane Grey's reading to gender support for James Stuart and the rights of Catholic claimants; appropriate or transgressive femininity figures the play's political stance. ${ }^{89}$ Uniquely, Banks's Jane Grey is the daughter of a monstrous mother, a reincarnation of Lady Macbeth who initiates the plot to put Jane on the throne and who wants equality for women..$^{\circ} \mathrm{A}$ foil to the bad woman whose lack of feminine obedience expresses 
itself in a disrespect for hereditary succession, Jane Grey is compliant and meek. The love object for Dudley, she is the advocate for both hereditary monarchy and the exclusion of women from power. Grey renders herself utterly powerless, in marriage and in government. Gilford arrives on stage commenting rather explicitly on the delights of his wedding night, her "panting side," her "balmy sighs" and "sweeter kisses;" seemingly invoking Donne's "The Sun Rising," Gilford praises his wife: "She, like the golden World, in Bed did lie,/Like conquering Alexander, I lay by." Jane herself lovingly identifies with being ruled, naming him, as he comes into her arms, "a greedy Conqueror of the world." Jane's wifely subordination grounds her stance on government: "This head was not made for Rule,/But to Obey; for here's my Lord;/To serve is all the scope of my Ambition." ${ }^{2}$ This is not the virtuous lack of ambition that signals fitness of rule but that which precludes it altogether.

When Jane Grey appears on stage reading a book in this play, the action displays her utter weakness. She reads with such feeling that Banks's Jane is scarcely rational, let alone intellectually combative. Just as Jane takes the throne for emotional reasons-Gilford has threatened to fall on his sword, and her mother has insinuated that she must do so to preserve their lives_-she reads feelingly. A stage direction indicates that she takes Plato to hand but weeps as she reads: "A Tyrant is the greatest Plague,/The Gods can send to men." As a result, she feels herself convicted of the crime of tyranny, and she lays down her book to fall supine on the floor. Jane is an emotional, passive reader who can be overpowered in every respect by what she reads, in her feelings, in her reason, and in her body. Her reading is the epitome of the passive, moral reading strategy recommended to women and of the emotional, physical, and even sexual abandonment that was often feared to be the result of women's reading, especially in private circumstances. ${ }^{93}$ Her reading, in effect, allows her to perform the political doctrine of "passive obedience," which developed after the Restoration to explain the actions required of subjects of a monarch who rules by “divine, indefeasible, hereditary right." 94 Jane's gendered passivity, registered in her reading, is an analogy for the passivity desired by a king's subjects; just as she obeys her husband, and submits to her books, she obeys the queen and supports the established line of succession. Her mother is a wicked, strong woman. She is not only ambitious but mad and "unnatural."95 For the Jacobite, only the "unnatural" woman would challenge hereditary monarchy, for that order depends on both gender hierarchy and hereditary succession; Jane Grey's reading conforms to the politically conservative construct of "natural" femininity. ${ }^{96}$

Alternatively, Jane Grey's reading could be used to justify political change. John Spurr argues that the Glorious Revolution, besides being "a palace coup, a dynastic 
reshuffle or a Dutch invasion," was also a "further political readjustment to the complex legacy of the Reformation;" William of Orange presented himself as the defender of Protestantism in England and some of his defenders saw his ascent as a "godly revolution" that would reconnect the Church of England with its Reformation roots. ${ }^{97}$ William was a "providential deliverer," and the revolution another of the signs of God's special concern for England's throne. ${ }^{98}$ The political events of 1688 did not see the disappearance of long-standing anxieties about deposition that played a role in the ascent of Queen Mary. Yet the manifestation of the divine right of kings in hereditary succession could encompass the idea that divine will might express itself in Providential political action, what J.C.D. Clark calls "providential divine right;" when God was acting through men, a Catholic monarch could be replaced by a Protestant one. ${ }^{99}$

Nicholas Rowe's 1715 publication of The Tragedy of the Lady Jane Gray takes up this strand of thought as he reflects on the Hanoverian succession that ended Stuart rule through its analysis of Grey's character and reading. Indeed, this play, along with the various commentaries about it, the biography The Life, Character, and Death, of the most Illustrious Pattern of Female Vertue, the Lady Jane Grey, the re-issue of Banks's play, and Edward Young's long poem, The Force of Religion; or, Vanquish'd Love (1715) are part of, according to Jean Marsden, a "brief but intense obsession with Lady Jane Grey” at the death of Queen Anne. ${ }^{100}$ Against a backdrop of 1715 's Jacobite uprising by the "Old Pretender," Rowe's play reflects on the ascent of George I to the throne in 1714, as the fifty-eighth in line to the throne and a man elevated by his Protestant faith and the Act of Settlement of 1701, which excluded Catholics. ${ }^{101}$ With the exception of Young's poem, all of these works and the several histories from the period represent Grey as a lively and articulate reader. ${ }^{102}$ Nicholas Rowe develops a reasonable version of Jane Grey in The Tragedy of the Lady Jane Gray to political purposes completely at odds with John Banks's emotional, if innocent, usurper. Jane does remain a love object, here for both the Earl of Pembroke and Guilford Dudley. Yet, after her marriage to Dudley Jane remains a virgin. This turn of events eschews female sexuality, as Jean Marsden observes, but also makes Jane free of the compulsions of domesticity and wifely obedience. ${ }^{103}$ Virginity facilitates an autonomous political role. She seeks advice before taking the throne and is informed that Edward's choice is legal; this Jane is neither compelled by her parents and husband nor driven by feeling. In addition to being a choice, her claim to the throne is treated as legitimate. A contemplative and scholarly reader, Jane Grey is assured of her role. As Guilford names her "Empress of the Watry World," she denounces such glory as a toy, as she prefers instead 
[... ] that blest Peace in which I once did dwell,

For Books, Retirement, and my studious Cell,

For all those Joys my happier Days did prove,

For Plato and his Academick Grove.

Despite her preference for studious retirement, she will take the crown because of public commitments, "To save this Land from Tyranny and Rome."104 Like a reformed Prospero, she takes the throne because it is her public duty. In an empress whose care for her country is stronger than her love of study, Rowe imagines a woman who is capable of both the retired and active life in ways more commonly allowed only to men. ${ }^{105}$ Rowe is censured for his efforts. An anonymous writer complains that the play is not sufficiently flattering to the current occupants of the throne, for his Jane is too critical of the institution of monarchy; Jane's reading of Greek, moreover, presents an impossible example for court ladies, a complaint that confirms Grey's status as exemplar but suggests that Rowe's representation of female reading is at odds with dominant conceptions of its value and methodology, which tend more to the vernacular, affective, and private. ${ }^{107}$ With Jane's reading, however, Rowe, creates a political woman, a virgin queen capable of reason who belongs on the throne. ${ }^{106}$

When the fortunes of Rowe's Jane Gray decline, he adds two more scenes of reading. First, Rowe's Jane, like Banks's, enters reading Plato's Phaedon (aloud in English). Here she comments on how Socrates takes his leave of life with a calm indifference, a position Guilford resists on conventionally gendered grounds: she is scorning a world that courts her "blooming Beauty." 107 Jane, however, remains more interested in the ethics of dying well. Rowe presents another tableau of reading after Jane and Guilford have been condemned to die. A stage direction establishes that "The Scene draws, and discovers the Lady Jane kneeling, as at her Devotion; a Light and a Book plac'd on a Table before her." The maid interprets the scene of reading religiously, as a sign of Jane's devotion. Guilford's gaze is erotic: "Mark her Vermillion Lip with Fervour, trembling!/Her spotless Bosom swells with sacred Ardor,/And burns with Ecstasy and strong Devotion." ${ }^{108}$ This is not Drayton's dead, beautiful object of desire, but a desirable reader. Rowe's Jane seems like the woman in Edward Young's Religion Vanquish'd, which praises the unity of virtue and beauty in Jane Grey's person. Such a woman has a reforming effect, according to Young: "We may fix our Eyes on a fair Example of Piety, to an utter Detestation of our Vices, and Gaze our selves into a Newness of Life." 109 Jean Marsden is critical of this scene because Rowe, she says, is unable to escape eroticizing his heroine and making her a sexual object. ${ }^{110}$ But he also allows the scene of reading to have political significance, 
for Marcia Pointon suggests that the religiously inflected eroticism of the sexually sublimated "fair penitent" with an impulse to martyrdom embodied the ideals of the eighteenth-century Protestant church. ${ }^{111}$ In Rowe's play, Jane Gray's reading is an emblem of the attractiveness of England's continued commitment to its Reformation history, now confirmed in the Act of Settlement. Certainly, support for the Act of Settlement underpins the construction of gendered reading practices in the play. Guildford's gaze at Jane reading elevates the pious, serious female mind in a world where learned ladies could become a source of anxiety and were sometimes caricatured as masculine or monstrous. Jane's erotic appeal confers acceptability on serious female reading. Moreover, if Guilford's gaze is erotic, Jane herself does not read erotically, and this too distinguishes Rowe's Jane Gray from dominant early modern representations of female reading, especially the languorous, sexualized female reader who gives herself over to romance and fiction, hinted at in Banks's play. Intelligent and godly, the method of Jane's reading supports the accession of the Hanovers. Jane Gray's pious femininity is politically persuasive. When she gives a book on the scaffold, not to the lieutenant but to her maid, Maria, the book is "the law of Everlasting Truth." This is the kind of claim that Jane Grey herself made in the sixteenth century; here it justifies the superior claim of Biblical law over political tradition, a point confirmed in the play's end, when Jane calls for God to "Raise up a Monarch of the Royal Blood,/Brave, Pious, Equitable, Wise, and Good,/[ ... ] To save thy Altars from the Rage of Rome." ${ }^{112}$ In this play, Jane Grey is the type to George I's anti-type. Grey's reading and that of women more generally, through her status as exemplar, is forged against that role.

\section{Conclusion}

The history of reading in early modern England is being written in the work of scholars like Anthony Grafton and Lisa Jardine, William Sherman, and Kevin Sharpe, and in the essay collections edited respectively by James Raven, Helen Small and Naomi Tadmor, by Jennifer Andersen and Elizabeth Sauer, and by Kevin Sharpe and Steven Zwicker. The particular history of women as readers, collectors, and writers about reading is also being developed by Heidi Brayman Hackel, Sasha Roberts, Mary Ellen Lamb, and Claire McManus; and it appears in my own previous work. Jane Grey does not appear in this history, just as she is not regularly discussed in histories of women's writing. Yet, she might occupy a more substantial place. Her writing illustrates the important function of reading and identifying oneself as a reader in constructing an early modern style and public identity. Jane Grey is also 
an intriguing figure because her writing, unlike that of so many other early female authors, has an extensive reception history. Publication of Grey's work and the subsequent transformation of her life and character as a reader and speaker document the interdependence of gender politics and political ideology. Jane Grey's militant texts were admired and reprinted by major Reformation writers seeking change and by seventeenth-century Protestants critical of the prevailing religio-political order. Later writers continued to use Jane Grey as a cipher for gender and political ideologies that underpin supposed truths — “interesting lies," to use Margaret Ferguson's term-about literacy. In a world where a reader's authority to determine meaning hung on structures of power, such as class, gender, and education, the representation of Jane Grey's reading draws into focus how the formation of female reading practices was informed by a broad spectrum of political conflicts, just as gender could rhetorically justify or critique political ideology. If Jane Grey's version of reading is one of "manful" combat, in which the Bible becomes a sword she might wield, the many different representations of her reading that followed highlight how women's reading endured as a site of political conflict.

\section{Notes}

1. Although Jane's surname was technically Dudley on her death, and consequently at the time in which these texts were produced, common usage identifies her as Jane Grey (or Gray). When referring to the literature about Jane Grey, or her husband, I use the name(s) employed in the poem or play.

2. The only contemporary edition of her work is Brief Confessional Writings: Grey, Stubbes, Livingstone and Clarksome. The Eary Modern Englishwoman: A Facsimile Library of Essential Works, Series 1: Printed Writings, 1500-1640: Part 2, vol. 2, ed. Mary Ellen Lamb (Aldershot: Ashgate, 2001). This edition is virtually unreadable, however, because it is a facsimile edition of Foxe's 1570 Actes and Monuments, a folio reproduced in a too-small scale. Lamb's introduction inaccurately claims that Foxe's Actes and Monuments contains the first printing of Jane Grey's work. See Mary Ellen Lamb, "Introductory Note," Brief Confessional Writings: Grey, Stubbes, Livingstone and Clarksome, p. ix-xv.

3. Biographies also treat Jane Grey's writing as evidence of her character, rather than as print publications engaged with specific historical circumstances. See Philip Sidney, Jane the Quene: Being Some Account of the Life and Literary Remains of Lady Jane Dudley Commonly Called Lady Jane Grey (London: Swan Sonnenschein, 1900); I.A. Taylor, Lady Jane Grey and Her Times (London: Hutchinson \& Co., 1908); Hester W. Chapman, Lady Jane Grey (London: Jonathan Cape, 1962); David Matthew, Lady Jane Grey: The Setting of the Reign (London: Eyre Methuen, 1972). 
4. Carole Levin, "Lady Jane Grey: Protestant Queen and Martyr," Silent But for the Word: Tudor Women as Patrons, Translators, and Writers of Religious Works, ed. Margaret Patterson Hannay (Kent, oH: Kent State University Press, 1985), p. 106. See also Carole Levin, "Lady Jane Grey," Sixteenth-Century British Nondramatic Writers. First Series, vol. 132, ed. David A. Richardson (Detroit and Washington, D.C.: Gale Research, 1996), pp. 149-53.

5. Lady Jane Grey, An epistle of the Ladye Jane a righte vertuous woman, to a learned man of late falne from the truth of Gods most holy word, for fear of the worlde ([London?]: [J. Day?], [1554?]: [STC 7279]; Lady Jane Grey, Here in this booke ye haue a godly epistle made by a faithful Christian A comunication betwene Fecknam and the Lady Jane Dudley. A letter that she wrote to her syster Lady Katherin. The ende of the Ladye Jane vpon the scaffolde. Ye shal haue also herein a godly prayer made by maister John Knokes (London: [Successor of A. Scoloker?], [1554?]: [STC 7279.5]). The seventeenth-century editions are as follows: Lady Jane Grey, The life, death and actions of the most chast, learned, and religious lady, the Lady Jane Gray, daughter to the Duke of Suffolke. Containing foure principall discourses written with her owne hands. The first an admonition to such as are weake in faith: the second a catechisme: the third an exhortation to her sister: and the last her words at her death (London: G. Eld, 1615: [STC 7281]); The life, death, and actions of the most chaste, learned, and religious lady, the Lady Jane Gray, daughter to the Duke of Suffolke (London: I. H[aviland], 1629: [STC 7281.5]); The life, death, and actions of the most chaste, learned, and religious lady, the Lady Jane Gray, daughter to the Duke of Suffolke (London: I. H[aviland], 1636: [STC 7282]).

6. John Foxe, Actes and monuments of matters most speciall and memorable, happenyng in the Church with an vniuersall history of the same, vol. 2. (London: John Daye, 1583: [STC 11225]), pp. 1419-23. Unless otherwise indicated, all references to Foxe are to this edition. BL Harley MS 416 A book in folio wherein is contained a collection of letters and other papers, formerly belonging to Mr. John Fox has the epistle to the learned man and the letter to Katherine (f.25-28v). Harley MS 2194, A Book in folio, much damnified by Moisture; and treating of the Lords High Stewards of England, from the time of $K$. William the Conqueror, to that of $K$. Charles I. with the trials of several criminals who were tried before them, and certaine other matters, has the letter to her father $(f .22 v-23)$. David Watson draws attention to the productions of the Genevan printer Jean Crespin, whose Troisième Partie du recueil des martyrs (1556) reprints the texts attributed to Jane Grey in the 1554 publication. Jane Grey appears alongside Bishops Cranmer, Ridley, and Latimer and preachers John Rogers and John Bradford. See David Watson, "Jean Crespin and the First English Martyrology," John Foxe and the English Reformation, ed. David Loades (Aldershot: Scolar Press, 1997), pp. 193-94, 199-200.

7. See Nicholas Harris Nicolas, "Memoir of Lady Jane Grey," The Literary Remains of Lady Jane Grey; with A Memoir of Her Life (London: Harding, Triphook, and Lepard, 1825), p.xcix; Catalogue of the Harleian Manuscripts, vol. 2. (1808), pp. 659-60. Nicolas suggests that the letter is for John Brydges, rather than Sir John Gage, as the Harleian 
Catalogue proposes. He says that Brydges was Lieutenant of the Tower, while Gage was constable in the fortress; he adds, as well, that Harley MS 2342 is the manuscript given to Thomas Bridges on the scaffold, where the recipient is identified (as in STC 7279.5) as the lieutenant's brother. Some versions of the scaffold speech identify the recipient of the book presentation as John Gage.

8. John N. King, English Reformation Literature: The Tudor Origins of the Protestant Tradition (Princeton: Princeton University Press, 1982), p. 419. King repeats this claim in "Fiction and Fact in Foxe's Book of Martyrs,"John Foxe and the English Reformation, ed. David Loades (Aldershot: Scolar Press, 1997), p. 18.

9. Wendy Wall, "Isabella Whitney and the Female Legacy," English Literary History 58.1 (1991), pp. 35-62; Frances Dolan, “'Gentleman, I have one more thing to say’: Women on Scaffolds in England, 1563-1680,” Modern Philology 92.2 (1994), pp. 157-78; Patricia Phillippy, Women, Death and Literature in Post-Reformation England (Cambridge: Cambridge University Press, 2002).

10. Levin, "Lady Jane Grey: Protestant Queen and Martyr," p. 92.

11. The lamentacion that Ladie Jane made, Saiyng for my fathers proclamacion now must I lese my heade. [A photostatic reproduction of a copy, now in the possession of the Marquis of Bath at Longleat] (London: John Wight, ca. 1570); Ulpian Fulwell, "A Commemoration of Queene Jane" and “An Epitaph on the death of Queene Jane," in The Flower of Fame (London: William Hoskins, 1575); Michael Drayton, "The Lady Jane Grey to the Lord Gilford Dudley” and "The Lord Gilford Dudley, to Lady Jane Grey," in Englands Heroicall Epistles (London: I.R., 1597); Thomas Dekker, The Famous History of Sir Thomas Wyat (London: E[dward]. A[1lde], 1607) —also printed in 1612; J.B. [John Banks]. The innocent usurper; or, The death of the Lady Jane Gray. A tragedy (London: R. Bentley, 1694) —also printed in 1715 and 1729; The ladies tales: exemplified in the vertues and vices of the quality, with reflections (London: Ferd. Burleigh; A. Dod; and J. Graves, 1714); The life, character, and death, of the most illustrious pattern of female vertue, the Lady Jane Gray, who was beheaded in the Tower at 16 years of age, for her stedfast adherence to the Protestant religion. Collected from the best historians. (London: J. Roberts, 1714); Nicholas Rowe, The tragedy of the Lady Jane Gray. As it is acted at the Theatre-Royal in Drury-Lane (London: Bernard Lintott, 1715) - also printed in 1718, 1720, 1727, 1730, 1733, 1736, 1750, 1754, 1755, 1756, 1761, 1764, 1774, 1782, and 1791; Charles Gildon, Remarks on Mr. Rowe's Tragedy of the Lady Jane Gray, and all his other plays ... (London: J. Roberts, 1715); W.R. Chetwood, The life of the Lady Jane Gray. With some remarks on the play. In a letter to a friend. (Dublin: G. Risk, 1715); The Bee. Select Poems from Books and Manuscripts (London: T. Ilive, 1715); Edward Young, The force of religion; or, vanquish'd love. (Illustrated in the story of the Lady Jane Gray.) A poem. In two books, 2nd. ed. (London: P.E. Curll and J. Pemberton, 1715) also printed in 1725, 1728, 1735, 1741, and 1762; "A lamentable Ditty on the Death of Lord Guildford Dudley, and the Lady Jane Grey," in A Collection of Old Ballads. Vol. 3 (London: printed for J. Roberts, 1725); The History and Fall, of the Lady Jane Grey in A Select Collection of Novels and Histories (London: n.p., 1729); James Cawthorn, "Lady 
Jane Grey to Lord Guilford Dudley, An Epistle. In the Manner of Ovid” in Poems, by the Rev. Mr. Cawthorn. Late master of Tunbridge School (London: printed by W. Woodfall, 1771), 97-109; Mary Scott, The Female Advocate; a Poem (London: printed for Joseph Johnson, 1774) — also printed in 1775; Elizabeth Singer Rowe, "Lady Jane Grey to Lord Guilford Dudley" and "Lord Guilford Dudley to Lady Jane Grey," in Friendship in Death (London: W. Osborne and T. Griffin, 1784); Lady Jane Grey: An Historical Tale. 2 vols. (London: William Lane, 1791); The History of Jane Grey, Queen of England with a defence of her claim to the crown (London: T. Wilkins, 1791) - also printed in 1792 and 1795 ?

12. Margaret Ferguson, Dido's Daughters: Literacy, Gender, and Empire in Early Modern England and France (Chicago and London: University of Chicago Press, 2003), pp. 7, 138.

13. David Loades, John Dudley: Duke of Northumberland 1504-1553 (Oxford: Clarendon Press, 1996), pp. 230-73; Christopher Haigh, English Reformations: Religion, Politics, and Society under the Tudors (Oxford: Clarendon Press; New York: Oxford University Press, 1993), pp. 203-18; A.G. Dickens, The English Reformation, 2nd ed. (University Park, PA: Pennsylvania State University Press, 1989), pp. 256-92.

14. John N. King accepts Foxe's identification of the learned man as John Harding on the authority of Lansdowne MS 2. See King, English Reformation Literature, p. 420. King and Dale Hoak, on the authority of William Haller, suggest that it may have been John Aylmer, formerly Jane Grey's tutor, who provided Foxe with manuscripts which supplement the texts originally printed. See Dale Hoak, "A Tudor Deborah? The Coronation of Elizabeth I, Parliament, and the Problem of Female Rule," John Foxe and His World, ed. Christopher Highley and John N. King (Aldershot: Ashgate, 2002), p. 75; John N. King, Foxe's Book of Martyrs and Early Modern Print Culture (Cambridge: Cambridge University Press, 2005), p. 26; William Haller, Foxe's Book of Martyrs and the Elect Nation (London: Jonathan Cape, 1963), p. 72.

15. Grey, An epistle of the Ladye Jane, p. Aii.

16. King, English Reformation Literature, p. 420.

17. Peter Auksi, Christian Plain Style: The Evolution of a Spiritual Ideal (Montreal and Kingston: McGill-Queen's University Press, 1995), pp. 222, 249, 271; Debora K. Shuger, Sacred Rhetoric: The Christian Grand Style in the English Renaissance (Princeton: Princeton University Press, 1988), pp. 64, 69.

18. Foxe, p. 1422.

19. Grey, An Epistle of the Ladye Jane, pp. Aii-Aiiiv.

20. King, "Fiction and Fact," p. 21.

21. Grey, An Epistle of the Ladye Jane, pp. Avi, Aviiiv.

22. Grey, An Epistle of the Ladye Jane, pp. Biii, Biiiiv.

23. Haigh, p. 179.

24. Lady Jane Grey, "Letters from Lady Jane Grey, to Henry Bullinger; with Translations," in The Literary Remains of Lady Jane Grey; with A Memoir of Her Life, by Nicholas Harris Nicolas (London: Harding, Triphook, and Lepard, 1825), pp.19-20. 
25. Nicolas, "Memoir of Lady Jane Grey," pp. lxxvii-lxxviii.

26. Frances E. Dolan, "Reading, Work, and Catholic Women's Biographies," English Literary Renaissance 33.3 (2003), pp. 328-57. See also Mary C. Erler, Women, Reading, and Piety in Late Medieval England (Cambridge: Cambridge University Press, 2002).

27. Grey, An Epistle of the Ladye Jane, pp. Bvi-Bviv.

28. Matthew, p. 134. For more on women and inheritance, see the chapter on the "Heiress at Law," in Eileen Spring, Law, Land, \& Family: Aristocratic Inheritance in England, 1300-180o (Chapel Hill and London: University of North Carolina Press, 1993), pp. 8-38.

29. For more on the history of attainder, see Michael Hicks, "Attainder, Resumption, and Coercion, 1461-1529," Parliamentary History 3 (1984), pp. 15-31.

30. Paula McQuade, “'Except that they had offended the Lawe': Gender and Jurisprudence in The Examinations of Anne Askew," Literature and History 3 (1994), pp. 1-14.

31. Grey, Here in this booke ye haue a godly epistle made by a faithful Christian, pp. BiiiBiiiv.

32. The Chronicle of Queen Jane, and of Two Years of Queen Mary. Written by a Resident of the Tower of London, ed. John Gough Nichols (London: The Camden Society, no. 48, 1849), p. v.

33. "Harleian MS 194," in The Chronicle of Queen Jane, pp. 32, 55.

34. Dolan, “'Gentleman, I have one more thing to say," p. 159.

35. Solt, p. 46 .

36. Thomas Cranmer, Certain sermons or homilies appointed to be read in churches. Book 1. (Excusum Londini: In aedibus Richardi Graftoni Regii Impressoris, [1551?]), p. Nviii.

37. Mary Ellen Lamb, "Constructions of Women Readers," Teaching Tudor and Stuart Women Writers, ed. Susanne Woods and Margaret P. Hannay (New York: Modern Language Association, 200o), pp. 23-34; Caroline McManus, Spenser's Faerie Queene and the Reading of Women (Newark: University of Delaware Press; London: Associated University Presses, 2002), pp. 29-48. See for instance Juan Luis Vives, A Very Fruiteful and Pleasant boke callyd the Instruction of a Christen Woman, trans. Richard Hyrde (Londini: In [a]edibus Thom[a] e Berth[eleti], 1541), f. $12 v$.

38. The Harleian Manuscripts catalogue proposes that the volume might have belonged to Edward Seymour, Duke of Somerset before coming into Grey's hands. Catalogue of the Harleian Manuscripts, vol. 2 (1808), pp. 659-60. Nicolas disagrees, proposing instead that the volume might have come Lady Jane's possession by way of her husband, whose brother John Dudley, the Earl of Warwick, was married to Anne Seymour, the daughter of the Duke of Somerset (57).

39. See The Book of Tobit, Chapter 3.

40. Harley Ms 2342, A velum Book of a small but thickish size, being the Manual of devotions of some English Protestant of Quality, who was cast into Prison wrongfully, according to his own Opinion (n.d), f. $27 v-29$.

41. Harley Ms 2342, f. 76. 
42. Harley MS 2342, f. 74-75v.

43. Harley MS 2342, f. 75 .

44. Harley Ms 2342, f. 78-8o.

45. Harley MS 2342, f. 79, 80.

46. Harley Ms 2342, f. $59 \mathrm{v}$.

47. Foxe, p. 1420.

48. Kevin Sharpe, Reading Revolutions: The Politics of Reading in Early Modern England (New Haven and London: Yale University Press, 2000), p. 66.

49. Haigh, p. 194.

5o. Elaine Beilin, "Introduction," The Examinations of Anne Askew, ed. Elaine Beilin (New York and Oxford: Oxford University Press, 1996), p. xxvi; Susan Brigden, London and the Reformation (Oxford: Clarendon Press, 1989), pp. 346, 347; Haigh, p. 161; Leo F. Solt, Church and State in Early Modern England, 1509-1640 (Oxford: Oxford University Press, 1990), pp. 46-56.

51. Cranmer, Aiiii-Biiiv.

52. Diarmaid MacCulloch, The Boy King: Edward VI and the Protestant Reformation (New York: Palgrave for St. Martin's Press, 1999), p. 159.

53. Peter Stallybrass, “Books and Scrolls: Navigating the Bible," Books and Readers in Early Modern England: Material Studies, ed. Jennifer Andersen and Elizabeth Sauer (Philadelphia: University of Pennsylvania Press, 2002), pp. 42-79; Jean-François Gilmont, "Protestant Reformations and Reading," A History of Reading in the West, ed. Guglielmo Cavallo and Roger Chartier, trans. Lydia G. Cochrane (Amherst: University of Massachusetts Press, 1999), pp. 213-37.

54. Diane Watt, Secretaries of God: Women Prophets in Late Medieval and Early Modern England (Cambridge: D.S. Brewer, 1997), p. 113; Christine Peters, Patterns of Piety: Women, Gender and Religion in Late Medieval and Reformation England (Cambridge: Cambridge University Press, 2003); Carole Levin, "Women in The Book of Martyrs as Models of Behaviour in Tudor England," International Journal of Women's Studies 4 (1981), pp.196-207; Jennifer Summit, Lost Property: The Woman Writer and English Literary History, 1380-1589 (Chicago and London: University of Chicago Press, 2000), pp. 109-61; Edith Snook, Women, Reading, and the Cultural Politics of Early Modern England (Aldershot: Ashgate, 2005), pp. 25-56; Megan L. Hickerson, Making Women Martyrs in Tudor England (Houndmills: Palgrave Macmillan, 2005).

55. Marsha S. Robinson, "Doctors, Silly Poor Women, and Rebel Whores: The Gendering of Conscience in Foxe's Actes and Monuments," John Foxe and his World, ed. Christopher Highley and John N. King (Aldershot: Ashgate, 2002), p. 237. See also Susan Wabuda, "The Woman with the Rock: The Controversy on Women and Bible Reading," Belief and Practice in Reformation England: A Tribute to Patrick Collinson, ed. Susan Wabuda and Caroline Litzenberger (Aldershot: Ashgate, 1998), pp. 40-59.

56. Roger Ascham, The scholemaster or plaine and perfite way of teachyng children, to vnderstand, write, and speake, the Latin tong (London: John Daye, 1570), pp. 11v-12. 
57. John Knox, "A Prayer of Mr. John Knokes," in Here in this booke ye haue a godly epistle made by a faithful Christian, p. Bivv.

58. Jane E. A. Dawson, "Knox, John (c.1514-1572)," Oxford Dictionary of National Biography (Oxford University Press, 2004). [<http://www.oxforddnb.com.proxy.hil.unb. $\mathrm{ca} /$ view/article/15781>, accessed 6 April 2007].

59. Loades, p. 196.

60. "An Exhortation written by the Lady Jane, the night before she suffered, in the end of her New Testament in Greek, which she sent to her sister Ladie Katherine," in Kleinot gnannt der Tod, by Otto Werdmüller, translated by Miles Coverdale as A moste frutefull, piththye and learned treatise, how a christen $m a[n]$ ought to behaue himself in the dau [n]ger of death ([Wesel?]: [H. Singleton?], [1555?]: [STC 25251]). Also published under the same title in 1574? [STC 25253] and 1595? [STC 25254].

61. John N. King says that it was Henry Bull, rather than Coverdale, who actually gathered the letters. See Foxe's Book of Martyrs and Early Modern Print Culture, p. 27.

62. Miles Coverdale, Certaine most godly, fruitful, and comfortable letters of such true Saintes and holy Martyrs of God, as in the lade bloodye persecution here within this Realme, gave their lyves for the defence of Christes holy gospel: written in the tyme of their affliction and cruell imprysonment. (London: John Day, 1564), p. Aii.

63. For more on this see, Mark Breitenberg, "The Flesh Made Word: Foxe's Actes and Monuments," Renaissance and Reformation/Renaissance et Réforme 13.4 (1989), pp. 381407; Peters, pp. 272, 273; John R. Knott, Discourses of Martyrdom in English Literature, 1563-1694 (Cambridge: Cambridge University Press, 1993), p. 57; Watt, p. 108; and Robinson, "Doctors, Silly Poor Women, and Rebel Whores," pp. 240-41.

64. Foxe's Actes and Monuments was published as a folio in the sixteenth and seventeenth centuries, in the years 1563, 1570, 1576, 1583, 1596/1597, 1610, 1631/1632, 1641, and 1684 . These editions reprint Jane Grey's writings. There are also several abridgements: a quarto by Timothy Bright (1589); a duodecimo by Clement Cotton (1613, 1614, 1615, $1625,1631,1633,1639,1658,1685)$; a folio by Thomas Mason (1615); and a 64 mo and octavo by John Taylor. Bright's abridgement mentions Jane Grey's execution but does not reprint her texts; The Mirror of Martyrs, Cotton's abridgement, includes Jane Grey's "effectual prayer” only; Thomas Mason's Christs victorie ouer Sathans tyrannie gives full or abbreviated versions of the dialogue with Feckenham, the letters to her father, the learned man, and Katherine, and her words on the scaffold. John Taylor's abridgement, only 22 pages in octavo, does not mention Jane Grey. For more on the popularity of Foxe's work and differences between editions in the sixteenth century, see Jesse Lander, “'Foxe's' Book of Martyrs: Printing and Popularizing the Actes and Monuments," Religion and Culture in Renaissance England, ed. Claire McEachern and Debora Shuger (Cambridge: Cambridge University Press, 1997), pp. 69-92. See also David Scott Kastan, "Little Foxes," John Foxe and his World, ed. Christopher Highley and John N. King (Aldershot: Ashgate, 2002), pp. 117-29; and King, Foxe's Book of Martyrs and Early Modern Print Culture, pp. 70-161.

65. King, Foxe's Book of Martyrs and Early Modern Print Culture, p. 27. 
66. King, Foxe's Book of Martyrs and Early Modern Print Culture, pp. 49-53.

67. Lady Jane Grey, Jane, by the grace of God quene of England, Fraunce and Ireland, defendor of the faith, of of the Church of Englande, of also of Irelande under Christ in earth the supreme head to al our most louing, faithfull, and obedient subiects, and to euery of them greting (London: Richard Grafton, 1553: [STC 7846]).

68. Nicolas, "Memoir of Lady Jane Grey," pp. li-lix.

69. Foxe, pp. 1419-20.

70. Foxe, p. 1420.

71. Robinson, "Doctors, Silly Poor Women, and Rebel Whores," pp. 235-48; Thomas Freeman, “'The Good Ministrye of Godlye and Vertuouse Women': The Elizabethan Martyrologists and the Female Supporters of Marian Martyrs," The Journal of British Studies 39.1 (2000), pp. 8-33; Ellen Macek, "The Emergence of Feminine Spirituality in the Book of Martyrs," Sixteenth Century Journal 19.1 (1988), pp. 62-80; Steven Mullaney, "Reforming Resistance: Class, Gender, and Legitimacy in Foxe's Book of Martyrs," Print, Manuscript, and Performance: The Relations of the Media in Early Modern England, ed. Arthur F. Marotti and Michael D. Bristol (Columbus: Ohio State University Press, 2000), pp. 235-51; Susannah Brietz Monta, "Foxe’s Female Martyrs and the Sanctity of Transgression," Renaissance and Reformation/Renaissance et Réforme 25.1 (2001), pp. 3-22.

72. Susannah Brietz Monta, Martyrdom and Literature in Early Modern England (Cambridge: Cambridge University Press, 2005), p. 12; Susan Felch, "Shaping the Reader in the Acts and Monuments," John Foxe and the English Reformation, ed. David Loades (Aldershot: Scolar Press, 1997), pp. 52-65.

73. G.R. Elton, "The Law of Treason in the Early Reformation," The Historical Journal 11.2 (1968), pp. 211-36; and Jonathan K. Van Patten, "Magic, Prophecy, and the Law of Treason in Reformation England," American Journal of Legal History 27.1 (1983), pp. 1-32.

74. Lady Jane Grey, The life, death and actions of the most chast, learned, and religious lady, the Lady Jane Gray (1615), pp. A2, A2v, C2.

75. According to the ESTC, between 1700 and 1800 , there are at least fifteen printings of Foxe's Actes and Monuments, in complete and abridged versions, under the title Book of Martyrs. Grey's writing is included in the abridged editions. For more on the eighteenth-century editions of Foxe's martyrology, see Eirwen Nicholson, "Eighteenth-Century Foxe: Evidence for the Impact of the Acts and Monuments in the 'Long' Eighteenth Century,” John Foxe and the English Reformation, ed. David Loades (Aldershot: Scolar Press, 1997), pp. 143-77. Jane Grey's works also appear in several other forms: the broadsheet, A Conference Between the Lady Jane Grey and F. Fecknam a Romish Priest, concerning the Blessed Sacrament; Whilest she was the Prisoner in the Tower of London, and was Beheaded on the Green there, Feb. 12. 1554. Together with her Behaviour and last Speech and Prayers at her Sufering (1688); "Lady Jane Grey's Letter to Her Sister, [ ... ] Translated from the Original Greek," in The Strange and Wonderful Predictions of Mr. Christopher Love (London: [1701?]); and the poem, "Written by 
Lady Jane Grey, when Prisoner in the Tower, with her Pin on her Chamber Wall," in Poems on several occasions. With Anne Boleyn to King Henry VIII. An epistle, by Elizabeth Tollet (1724).

76. One exception to this is a ballad: The lamentacion that Ladie Jane made, Saiyng for my fathers proclamacion now must I lese my heade. (See note 11). This versified version of Jane's speech on the scaffold concludes with Jane giving away her handkerchief and book. On the scaffold she presents a book "covered all with golde," a garbled sketch of the Greek Testament not covered in gold that Jane Grey gave her sister.

77. Levin, "Lady Jane Grey: Protestant Queen and Martyr," p. 105.

78. Ulpian Fulwell, "A Commemoration of Queene Jane," and "A Preamble to this parte of the Booke following," in The Flower of Fame, pp. 39, 42.

79. Thomas Bentley, The Monument of Matrones (London: Printed by Henry Denham, 1582), vol. 2, pp 98-102; vol. 1, pp. A2-B5.

8o. Michael Drayton, Englands Heroicall Epistles (London: Printed by I.R., 1597), p. 71.

81. Drayton, p. $73 v$.

82. Drayton, p. $75 v-77$; Foxe, p. 1423.

83. Cyrus Hoy, Introductions, Notes, and Commentaries to Texts in 'The Dramatic Works of Thomas Dekker,' ed. Fredson Bowers, vol. 1 (Cambridge: Cambridge University Press, 1980), pp. 311-313. For more on this play, see Julia Gasper, The Dragon and the Dove: The Plays of Thomas Dekker (Oxford: Clarendon Press, 1990), pp. 44-61.

84. Thomas Dekker, The Famous History of Sir Thomas Wyat, in The Dramatic Works of Thomas Dekker, ed. Fredson Bowers, vol. 1 (Cambridge: Cambridge University Press, 1953), pp. 397-459.

85. Marsha S. Robinson, Writing the Reformation: Actes and Monuments and the Jacobean History Play (Aldershot: Ashgate, 2002), p. 131.

86. Julie Crawford, "Fletcher's 'The Tragedie of Bonduca' and the Anxieties of the Masculine Government of James I," Studies in English Literature, 1500-1900 39.2 (1999), pp. 357-81.

87. A Conference Between the Lady Jane Grey and F. Fecknam a Romish Priest, concerning the Blessed Sacrament; Whilest she was the Prisoner in the Tower of London, and was Beheaded on the Green there, Feb. 12. 1554. Together with her Behaviour and last Speech and Prayers at her Sufering (1688).

88. J.B. [John Banks]. The innocent usurper; or, The death of the Lady Jane Gray. A tragedy. (London: R. Bentley, 1694), p. A2.

89. William Van Lennep, The London Stage: 1660-180o, part 1 (Carbondale, IL: Southern Illinois University Press, 1965). A comment in the Gentleman's Journal (April 1692) indicates that "Mr Banks hath writ a Tragedy call'd the Innocent Usurper ... However, there being some reasons which hinder it from appearing on the Stage, he designs to submit it to the Judgment of every Impartial Reader, and it will very speedily appear in print" (407). It was printed in 1694, but not acted (426).

90. Banks, p. 29, 1.

91. Banks, p. 8. 
92. Banks, p. 14, 16, 18 .

93. Roger Chartier, “The Practical Impact of Writing," A History of Private Life. Vol. 3. Passions of the Renaissance, ed. Roger Chartier, trans. Arthur Goldhammer (Cambridge, MA: Belknap Press of Harvard University, 1989), pp. 130-47; Naomi Tadmor, "In the even my wife read to me': Women, Reading and Household Life in the Eighteenth Century," The Practice and Representation of Reading in England (Cambridge: Cambridge University Press, 1996), pp. 162-174.; William Beatty Warner, "Staging Readers Reading," Eighteenth-Century Fiction 12.2-3 (2000), pp. 391-416; Patricia Howell Michaelson, "Women in the Reading Circle," Eighteenth Century Life 13 (1989), pp. 59-69.

94. Clark, pp. 58, 84; Paul Kleber Monod, Jacobitism and the English People 1688-1788 (Cambridge: Cambridge University Press, 1989), pp. 18-19.

95. Banks, p. 37.

96. Monod, p. 22.

97. John Spurr, The Post-Reformation: Religion, Politics and Society in Britain 1603-1714 (Harlow: Longman, 2006), pp. 179, 204. William Gibson also argues that the supporters of the Revolution turned not just to the Bible but to the Reformation to justify their position. The Church of England 1688-1832: Unity and Accord (London and New York: Routledge, 2001), p. 36.

98. On the king and ideas of providence, see Spurr, p. 185 and Gibson, pp. 42-46.

99. J.C.D. Clark, English Society 1660-1832: Religion, Ideology and Politics During the Ancien Regime (Cambridge: Cambridge University Press, 2000), pp. 86-91.

100. Jean I. Marsden, Fatal Desire: Women, Sexuality, and the English Stage, 1660-1720 (Ithaca and London: Cornell University Press, 2006), p. 171.

101. Clark, p. 95; Julian Hoppitt, A Land of Liberty? England 1689-1727 (Oxford: Oxford University Press, 2002), pp. 37-45.

102. The histories refer to Jane Grey as a reader: The life, character, and death, of the most illustrious pattern offemale vertue, the Lady Jane Gray, who was beheaded in the Tower at 16 years of age, for her stedfast adherence to the Protestant religion. Collected from the best historians, esp. pp. 6 and 23-26; Chetwood, p. 3. To the usual details about Aylmer, Ascham, and Plato, Chetwood adds another story to prove her "Veneration for Holy Writ;" Jane Grey falls into a state of melancholy and expresses resentment towards a companion who stood on a Bible to get something above her reach.

103. Marsden, pp. $185-89$.

104. Nicholas Rowe, p. 37.

105. This section of the play is reprinted as "Royalty and Popery," in The Bee, pp. 30-38.

106. Remarks on the Tragedy of the Lady Jane Grey; in a Letter to Mr. Rowe (London: Printed for J. Roberts, [1715].

107. Nicholas Rowe, p. 46.

108. Nicholas Rowe, pp. 58, 59.

109. Young, p. [A4].

110. Marsden, pp. 190, 191. 
'Manful' Combat, and the Female Reader in Early Modern England 81

111. Marcia Pointon, Strategies for Showing: Women, Possession, and Representation in English Visual Culture (Oxford: Oxford University Press, 1997), p. 229-306.

112. Nicholas Rowe, p.64, 65. 